\title{
Down-regulation of Langerhans cell protein kinase C- $\beta$ isoenzyme expression in inflammatory and hyperplastic dermatoses
}

\author{
N.J.REYNOLDS, J.Y.YI, G.J.FISHER, K.D.COOPER, J.J.VOORHEES AND \\ C.E.M.GRIFFITHS \\ Department of Dermatology, University of Michigan Medical Center, Ann Arbor, MI, U.S.A. \\ Accepted for publication 19 October 1994
}

Summary The family of protein kinase C (PKC) isoenzymes plays a fundamental part in signal transduction, and thereby regulates important cellular functions, including growth, differentiation, cytokine production and adhesion molecule expression. In lesional psoriatic skin, $\mathrm{Ca}^{2+}$-dependent $\mathrm{PKC}$ activity, PKC- $\beta$ protein and epidermal Langerhans cell (LC) PKC- $\beta$ immunostaining are significantly decreased, indicating activation and subsequent down-regulation of PKC. Whether these changes occur in other inflammatory/hyperplastic dermatoses is, however, unknown. We examined PKC- $\alpha$ and PKC- $\beta$ expression in normal skin, psoriasis, cutaneous T-cell lymphoma (CTCL), lamellar ichthyosis, non-bullous ichthyosiform erythroderma, atopic dermatitis, urushiol-induced allergic contact dermatitis, and sodium lauryl sulphate (SLS)-induced irritant contact dermatitis. Cryostat sections were stained for PKC- $\alpha$ and PKC- $\beta$, and the LC marker CD1a, using an immunoperoxidase technique and specific monoclonal antibodies.

Double-labelling studies, in normal skin, revealed co-expression of PKC- $\beta$ and $\mathrm{CD} 1 \mathrm{a}$ by epidermal LCs. Analysis of the number of PKC- $\beta^{+}$and $\mathrm{CD}^{+} \mathrm{a}^{+}$epidermal LCs, in diseased compared with normal skin, revealed three categories: (i) in psoriasis and CTCL, the PKC- $\beta^{+}$ epidermal LC number was significantly reduced, whereas the $\mathrm{CD}^{-\mathrm{a}^{+}}$epidermal LC number was unchanged; (ii) in allergic and irritant contact dermatitis, both PKC- $\beta^{+}$and $\mathrm{CD} 1 \mathrm{a}^{+}$epidermal LCs were significantly reduced in number; and (iii) in atopic dermatitis, the PKC- $\beta^{+}$epidermal LC number was normal, and $\mathrm{CD}^{2} \mathrm{a}^{+}$epidermal LCs were significantly increased in number. Moreover, the ratio of epidermal $\mathrm{LC} \mathrm{PKC}^{+} / \mathrm{CD}^{+} \mathrm{a}^{+}$was reduced in all the dermatoses studied, suggesting activation of PKC- $\beta$, with subsequent down-regulation. Within the dermis, increased PKC- $\beta$ staining of infiltrating cells was observed in all the conditions'studied except lamellar ichthyosis and non-bullous ichthyosiform erythroderma. These data indicate that: (i) downregulation of LC PKC- $\beta$ occurs in a variety of inflammatory and hyperplastic skin disorders, and is not unique to psoriasis, and (ii) the pattern of epidermal LC PKC- $\beta$ and CD1a expression varies among the diseases studied. In mice, PKC activation induces LC migration. Thus, downregulation of epidermal LC PKC- $\beta$ associated with reduced $\mathrm{CD}_{1} \mathrm{a}^{+}$epidermal $\mathrm{LCs}$ in allergic and irritant contact dermatitis suggests that PKC- $\beta$ may transduce the signal for migration of LCs from human epidermis.

The family of protein kinase C (PKC) isoenzymes plays a key part in transducing signals from cell

\footnotetext{
Presented, in part, at the Annual Meeting of the Society for Investigative Dermatology, Washington, DC, U.S.A., 28-30 April 1993. N.J.Reynolds is now at the Department of Dermatology. Royal Victoria Infirmary, Newcastle upon Tyne NE1 4LP and C.E.M.Griffiths is now at the Department of Dermatology, University of Manchester School of Medicine.
}

surface receptors to the interior of the cell, and thereby regulates a wide variety of cell functions. ${ }^{1}$ The binding of extracellular factors, inflammatory mediators, and growth factors to their specific cell surface receptors results in receptor activation and, in many instances, activation of phospholipase C (PLC). ${ }^{1}$ PLC catalyses hydrolysis of membrane-associated inositol-containing phospholipids (phosphatidylinositol) 
to yield at least two important second messengers. inositol trisphosphate, which mobilizes calcium from intracellular stores, and 1,2-diacylglycerol (1,2-DAG), the physiological activator of PKC. Ligand-cell surface receptor interaction may also result in hydrolysis of choline-containing phospholipids (phosphatidylcholine), through the action of phosphatidylcholinespecific PLC or phospholipase D, and lead to the formation of 1,2-DAG and activation of $\mathrm{PKC}^{2,3}$ Tumour-promoting phorbol esters, for example 12-0tetradecanoylphorbol-13-acetate (TPA), directly bind to and activate PKC.

PKC comprises a family of isoenzymes, encoded by at least nine genes, which display selective organ and cellular expression, ${ }^{1,2,4-8}$ and exhibit functional diversity, ${ }^{1,2,9,10}$ suggesting that different isoenzymes may have different physiological roles. PKC isoenzymes are classified into calcium-dependent (PKC- $\alpha \beta \mathrm{I}$, BII and $\gamma)$, calcium-independent (PKC- $\delta, \epsilon, \eta(\mathrm{L})$, and $\theta)$, and atypical $[\zeta$ and $\iota(\lambda)]$ forms. $^{2,5}$ PKC- $\alpha, \beta \mathrm{I}, \beta \Pi, \delta, \epsilon, \zeta$ and $\eta$ have been detected in human skin. ${ }^{7,8}$ It is of interest that PKC- $\beta$ appears to be abundantly expressed by epidermal Langerhans cells (LC), ${ }^{7,11,12}$ Furthermore, application of TPA or synthetic diglyceride to mouse and human skin results in downregulation of $\mathrm{Ca}^{2+}$-dependent PKC activity, ${ }^{13}$ a reduction of epidermal LCs, and suppression of allergic contact dermatitis. ${ }^{14-16}$

PKC activation is associated with rapid translocation of the enzyme from the cytosol to the membrane, and this is followed by proteolysis. ${ }^{17}$ Thus, prolonged activation of PKC results in its down-regulation. However, PKC isoenzymes vary in their susceptibility to translocation and down-regulation, possibly due to differences in subcellular localization and requirements for different co-factors, and this appears to be cell type-dependent. ${ }^{8,17}$

PKC regulates epidermal growth, differentiation, expression of adhesion molecules and leucocyte trafficking. ${ }^{18-20}$ Recent studies indicate that there are significant abnormalities of PKC signalling in psoriasis: (i) both soluble and membrane-bound PLC activities are significantly elevated in lesional psoriatic epidermis compared with non-lesional and normal epidermis ${ }^{21-23}$ (ii) 1,2-DAG mass is significantly higher in psoriatic lesional skin compared with normal skin; ${ }^{22}$ (iii) PKC activity is significantly decreased in both lesional and non-lesional psoriatic epidermis compared with normal skin; ${ }^{24,25}$ (iv) PKC$\alpha$ and PKC- $\beta$ protein levels are reduced in psoriatic epidermis compared with normal, as assessed by
Western analysis and immunohistochemistry. ${ }^{7}$ However, whether these changes are specific for psoriasis is currently unknown. To address this question, we have used immunohistochemical techniques to examine the expression of PKC- $\alpha$ and PKC- $\beta$ isoenzymes and the concurrence of PKC- $\beta$ and CD1a in LCs, in a variety of inflammatory and hyperplastic dermatoses.

\section{Methods}

\section{Patients}

Fifteen adult volunteers (10 males, five females; mean age 38 years, range $20-55$ ), who were otherwise in good health and taking no medication, were recruited for study. Seven of the volunteers (six male, one female; mean age 35 years, range 20-55 years) gave a history of poison ivy dermatitis. Patients with clinical and histological features of lamellar ichythosis (three female; mean age 38 years, range 24-47), non-bullous ichthyosiform erythroderma (three male; mean age 24 years, range 23-27), atopic dermatitis (two male, three female; mean age 36 years, range 21-56), cutaneous T-cell lymphoma (CTCL, four male, two female; mean age 51 years, range $37-81$ ), and psoriasis (five male, two female; mean age 44 years, range 30-57), were also selected for study. The study was approved by the University of Michigan Medical Center institutional review board, and all patients gave written informed consent to participation.

\section{Induction of irritant and allergic contact dermatitis}

For induction of allergic contact dermatitis, urushiol was applied to the seven volunteers who gave a history of poison ivy dermatitis. ${ }^{26}$ Twenty microlitres of urushiol (poison ivy/oak mixture, Hollister-Stier, Elkhart, IN, U.S.A.), 1:50 in ethanol, was applied under occlusion, using the Altest System (Sodertalje, Sweden), to four different sites $(5 \mathrm{~mm}$ diameter, $5 \mathrm{~cm}$ apart) on the buttock. Evaluations and punch biopsies were performed at $0,1,8,24$ and $48 \mathrm{~h}$ after application.

For induction of irritant contact dermatitis, sodium lauryl sulphate (SLS, $2 \%$ in Retin $A^{\mathbb{R}}$ vehicle, Ortho Pharmaceutical, Raritan, NJ. U.S.A.) and vehicle were applied under occlusion to the buttocks of eight volunteers, as previously described, ${ }^{27,28}$ and punch biopsies were performed 4 days later. 

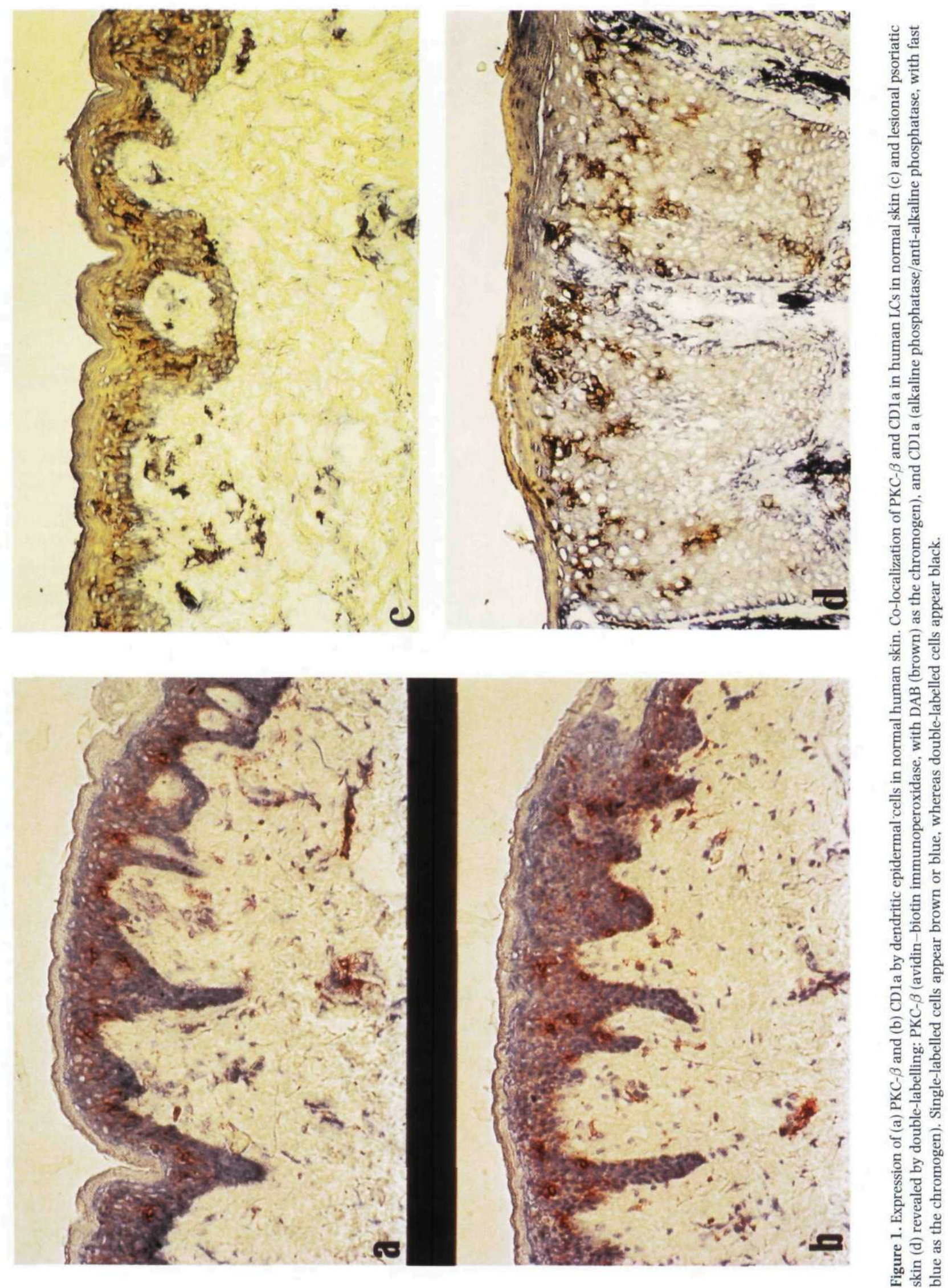

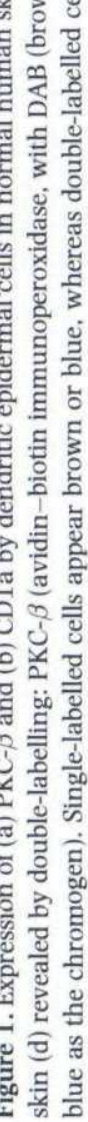



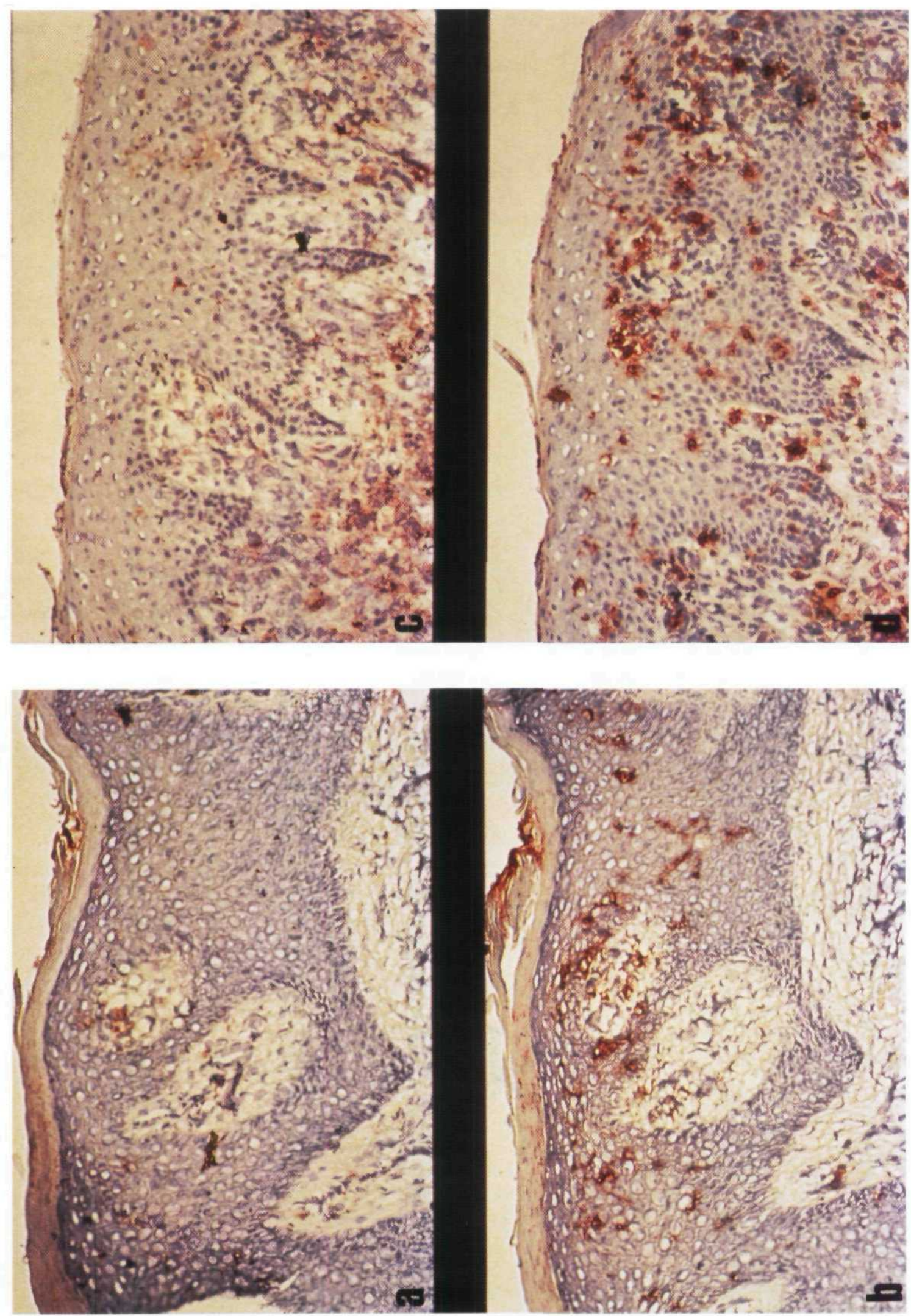

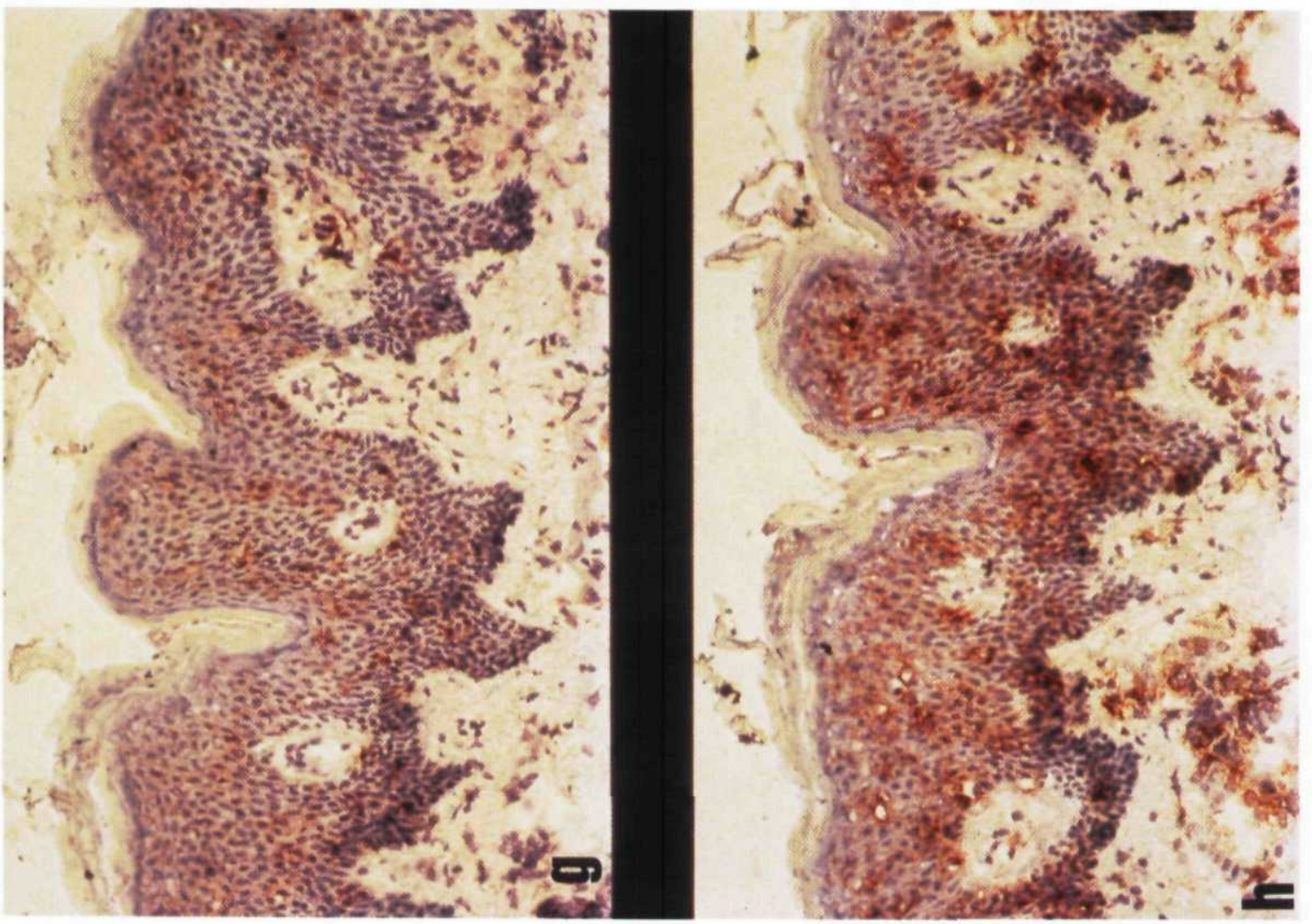

है

클

อิ हี

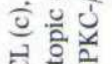

究

모ำ

ปे

诺

일

焉豆

象

a

ธิ

बิ

믈 을

을.

ఏ它可

गे.

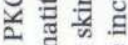

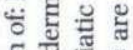

额苋

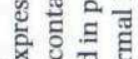

क्षे 행

) न
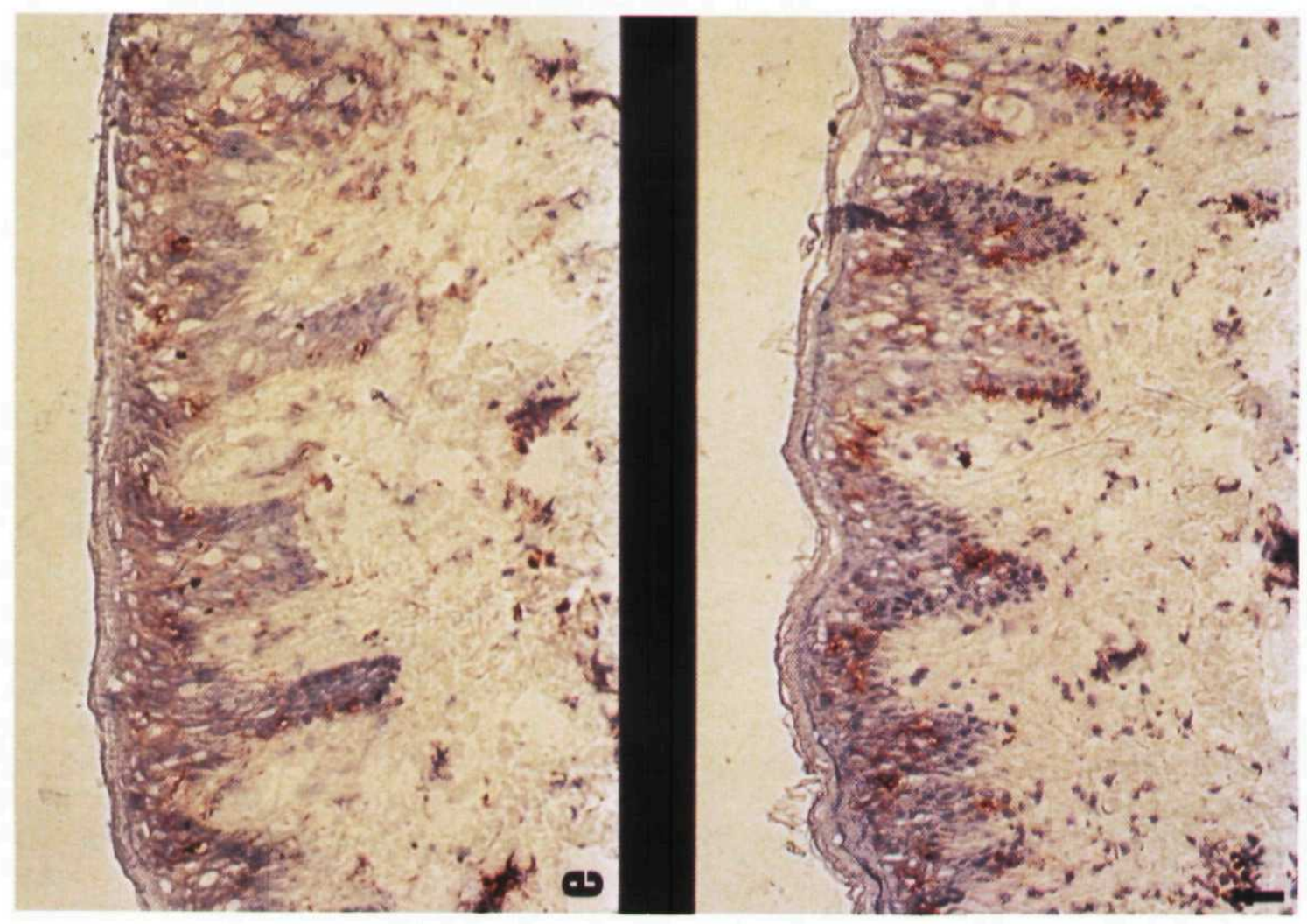

हु छ

돌

응

롤근

슬 웜

픔

든

萢

열

a

등 흥

氙 焉

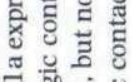

ठิ एँ

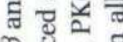

늘

능 需

돌 롤 능

焉表药

एर ज्ञ

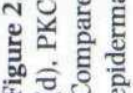




\section{Biopsy procedure}

Four-mm punch biopsies, obtained under local anaesthesia, were embedded in optimal cutting temperature (OCT) compound (Miles Laboratories, Elkhart, IN, U.S.A.), frozen in isopentane, precooled by liquid nitrogen, and stored at $-70^{\circ} \mathrm{C}$ until analysis.

\section{Immunohistochemistry}

Five-micron sections were cut on a cryostat, and stained with monoclonal antibodies to PKC- $\alpha$, PKC- $\beta$ (Seikagaku, Rockville, MD, U.S.A.), or CD1a, a LC marker, (Becton Dickinson, Burlingame, CA, U.S.A.). PKC- $\alpha$ and PKC- $\beta$ antibodies have previously been characterized, ${ }^{29,30}$ and shown to detect appropriate molecular weight proteins in skin by Western analysis. ${ }^{7}$ Substitution of the primary antibody with isotype-specific IgG, and omission of the primary antibody, served as negative controls. When using single antibodies, sections were developed using an avidin-biotin immunoperoxidase technique (Vectastain $\mathrm{ABC}$, Vector Laboratories, Burlingame, CA, U.S.A.), with 3-amino 9-ethylcarbazole (AEC) as the chromogen, and counterstained with $1 \%$ haematoxylin. For double-staining, the first antibody was visualized using an avidin-biotin immunoperoxidase technique, with 3,3'-diaminobenzidine $(\mathrm{DAB})$ as the chromogen, and the second antibody visualized using an alkaline phosphatase/anti-alkaline phosphatase technique, with fast blue as the chromogen, as described previously. ${ }^{31}$

\section{Assessment of staining}

The numbers of PKC- $\beta^{+}$and CD1 ${ }^{+}$epidermal LCs in four high-power fields (objective $\times 40$ ) were counted by a single observer. The staining intensity of PKC$\beta^{+}$epidermal LCs, and the degree of PKC- $\beta$ staining in the dermis, were evaluated by two observers using an ordinal $0-4$ scale, where $0=$ no staining; $1=$ minimal; $2=$ minimal-moderate; $3=$ moderate; and $4=$ maximal staining.

\section{Statistical analysis}

The two-sample $t$-test was used to compare the number and staining intensity of PKC- $\beta^{+}$and $\mathrm{CD} 1 \mathrm{a}^{+}$ cells in the epidermis and dermis of normal volunteers vs. patients with the aforementioned dermatoses. Comparisons of $\mathrm{PKC}-\beta^{+} / \mathrm{CD} 1 \mathrm{a}^{+}$ratio among the dermatoses studied were performed by the analy- sis of variance method and the least-significance-test. The paired $t$-test was used to compare sites of experimentally induced irritant or allergic contact dermatitis with the control site in the same individual. All $P$ values are two-sided. Summary statistics are represented as means \pm SEM. The data were analysed with the Michigan Interactive Data Analysis System, a statistical software package developed by the Center for Statistical Consultation and Research at the University of Michigan.

\section{Results}

Co-localization of PKC- $\beta$ and CD1 $a$ in human Langerhans cells

In normal skin, immunostaining with PKC- $\beta$ revealed strong expression in epidermal and dermal dendritic cells, and weak keratinocyte staining (Fig. 1), as previously reported. ${ }^{7}$ Double-labelling showed co-localization of PKC $-\beta$ and CD1a in epidermal dendritic cells, confirming that these cells were LCs (Fig. 1).

\section{Expression of PKC- $\alpha$ and PKC- $\beta$ isoenzymes in inflammatory and hyperplastic dermatoses}

PKC- $\alpha$ expression. Immunostaining with PKC- $\alpha$ revealed weak keratinocyte and dermal expression, which was unaltered in the diseases studied (data not shown).

PKC $-\beta$ expression. Compared with PKC- $\beta$ immunostaining observed in normal skin, significant alterations of epidermal and/or dermal PKC- $\beta$ expression were observed in all of the disease states studied, except for non-lesional psoriatic skin (Figs 2-4).

Analysis of the number of $\mathrm{PKC}-\beta^{+}$and $\mathrm{CD} 1 \mathrm{a}^{+}$ epidermal LCs in the dermatoses studied, compared with normal skin, revealed three categories (Fig. 3 and Table 1). (i) The number of PKC- $\beta^{+}$LCs/h.p.f. was significantly lower in lesional psoriatic skin and CTCL, than in normal skin $(P<0.005)$, whereas the number of $\mathrm{CD} \mathrm{a}^{+}$epidermal LCs/h.p.f. was not significantly different (Figs 2 and 3). Consistent with this, the ratio of $\mathrm{PKC}-\beta^{+} / \mathrm{CD} 1 \mathrm{a}^{+}$epidermal LCs was $0 \cdot 33 \pm 0.05$ in lesional psoriatic skin and $0 \cdot 51 \pm 0 \cdot 1$ in CTCL, compared with $0.82 \pm 0.03$ in normal skin $(P<0 \cdot 005)$. (ii) The number of PKC- $\beta^{+}$and $C D 1 a^{+}$ epidermal LCs/h.p.f. was reduced in urushiol-induced allergic contact dermatitis at $24 \mathrm{~h}$, and SLS-induced 


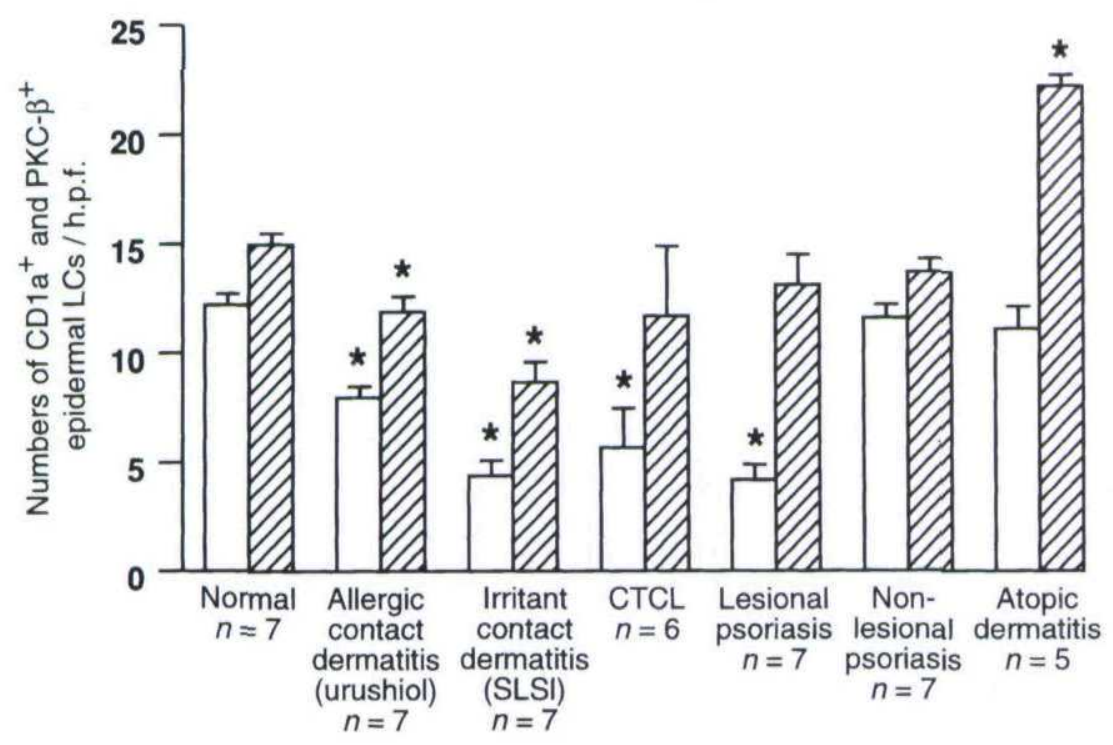

Figure 3. Numbers of PKC $-\beta^{+}$and $\mathrm{CD} 1 \mathrm{a}^{+}$ epidermal Langerhans cells in inflammatory and hyperplastic dermatoses. All values are means \pm SEM. ${ }^{*} P<0.05$ compared with normal skin. $\square, \mathrm{PKC}-\beta^{+}:$, $\mathrm{CD} 1 \mathrm{a}^{+}$. irritant contact dermatitis, compared with normal skin, or vehicle in the case of SLS-induced irritant contact dermatitis $(P<0.05$; Figs 2 and 3$)$. The reduction of PKC- $\beta^{+}$epidermal LCs could be due, in part, to movement of PKC $-\beta^{+} / \mathrm{CD}^{-} \mathrm{a}^{+} \mathrm{LCs}$ out of the epidermis. However, the ratio of $\mathrm{PKC}-\beta^{+} / \mathrm{CD} 1 \mathrm{a}^{+}$epidermal LCs was significantly reduced in SLS-treated skin $(0.53 \pm 0.07) \quad$ compared with vehicle $(0.73 \pm 0.03 ; \quad P<0.05)$, and showed a trend towards reduction in urushiol-treated skin $(0 \cdot 68 \pm 0 \cdot 03)$ compared with $0 \cdot 82 \pm 0 \cdot 03$ in normal skin $(P=0.06)$. These data suggest that reduction of PKC- $\beta^{+}$epidermal LCs could not be fully accounted for by migration of PKC $-\beta^{+} / \mathrm{CD} 1 \mathrm{a}^{+} \mathrm{LCs}$ out of the epidermis, and that LC PKC- $\beta$ was activated and then down-regulated during urushiol-induced allergic con-

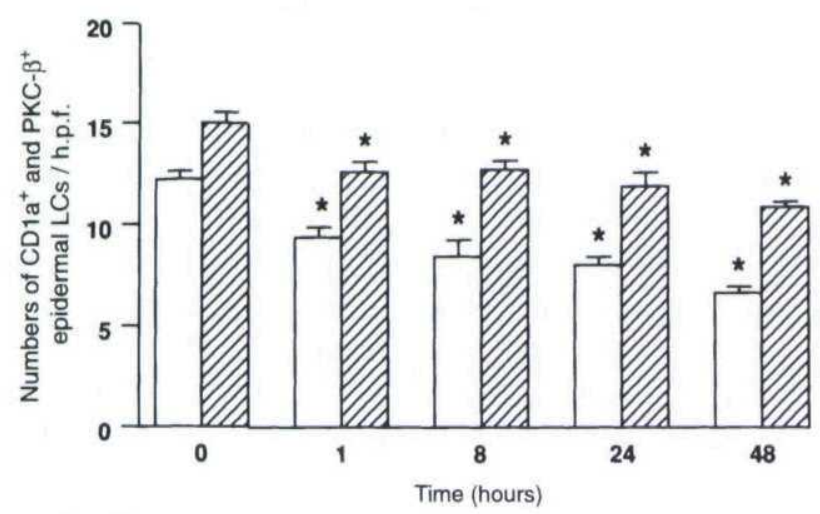

Figure 4. Time-course of PKC- $\beta$ and CD1a expression in urushiolinduced allergic contact dermatitis. All values are means \pm SEM, $n=7 .{ }^{*} \mathrm{P}<0.05$ compared with normal skin. $\square, \mathrm{PKC}-\beta^{+} ; \varpi, \mathrm{CD} 1 \mathrm{a}^{+}$. tact dermatitis and SLS-induced irritant contact dermatitis. (iii) The number of $\mathrm{CD}^{+} \mathrm{a}^{+}$epidermal LCs/ h.p.f. was significantly increased in atopic dermatitis, compared with normal skin $(P<0.0001)$, as previously reported. ${ }^{32}$ There was, however, no corresponding increase in the number of PKC- $\beta^{+}$epidermal LCs, compared with normal skin, and indeed the intensity of PKC- $\beta$ epidermal LC staining was reduced $(1 \cdot 6 \pm 0 \cdot 1)$ compared with normal skin $(2 \cdot 4 \pm 0 \cdot 1$; $\mathrm{P}<0.005)$. Moreover, the ratio of $\mathrm{PKC}-\beta^{+} / \mathrm{CD} 1 \mathrm{a}^{+}$epidermal LCs was significantly decreased in atopic dermatitis (0.5 0.05$)$ compared with normal skin $(0.82 \pm 0.03 ; P<0.001)$, suggesting modulation of epidermal LC PKC- $\beta$ in atopic dermatitis.

In order to examine the effects of epidermal hyperplasia in isolation, i.e. in the absence of inflammation, on PKC- $\beta$ immunostaining, we investigated patients with lamellar ichthyosis and non-bullous ichthyosiform erythroderma. We observed significantly reduced numbers of PKC- $\beta^{+}$epidermal LCs/ h.p.f. in lamellar ichthyosis $(5 \cdot 8 \pm 1 \cdot 1)$ and non-bullous ichthyosiform erythroderma $(5 \cdot 4 \pm 1 \cdot 8)$, compared with normal skin $(12 \cdot 2 \pm 0 \cdot 4 ; P<0.005)$. A trend towards a reduction of $\mathrm{CD}^{+} \mathrm{a}^{+}$epidermal $\mathrm{LC}$ number was also observed $(P=0 \cdot 06)$ in lamellar ichthyosis, but not in non-bullous ichthyosiform erythroderma. In addition, the ratio of $\mathrm{PKC}-\beta^{+} / \mathrm{CD} 1 \mathrm{a}^{+}$ epidermal LCs was significantly reduced in lamellar ichthyosis $(0.53 \pm 0.01)$ and non-bullous ichthyosiform erythroderma $(0 \cdot 40 \pm 0 \cdot 1)$, compared with normal skin $(0.82 \pm 0.03 ; P<0.005)$. These data suggest that modulation of epidermal LC PKC- $\beta$ 


\begin{tabular}{lcc}
\hline Condition & $\begin{array}{c}\text { Number of PKC- } \beta^{+} \\
\text {epidermal LCs }\end{array}$ & $\begin{array}{c}\text { Number of CDla }{ }^{+} \\
\text {epidermal LCs }\end{array}$ \\
\hline $\begin{array}{l}\text { Psoriasis } \\
\text { CTCL }\end{array}$ & $\downarrow$ & $\rightarrow$ \\
Lamellar ichthyosis & & \\
$\begin{array}{l}\text { Non-bullous ichthyosiform } \\
\text { erythroderma }\end{array}$ & $\downarrow$ & $\downarrow$ \\
$\begin{array}{l}\text { Urushiol-induced allergic } \\
\text { contact dermatitis }\end{array}$ & $\downarrow$ & $\uparrow$ \\
$\begin{array}{l}\text { SLS-induced irritant } \\
\text { contact dermatitis } \\
\text { Atopic dermatitis }\end{array}$ & $\rightarrow$ & $\downarrow$ \\
\hline
\end{tabular}

Table 1. Summary of changes in number of PKC $-\beta^{+}$and $\mathrm{CDla}{ }^{+}$epidermal Langerhans cells in inflammatory and hyperplastic skin diseases

LCs, Langerhans cells; CTCL, cutaneous T-cell lymphoma; SLS, sodium lauryl sulphate.

expression may occur in the absence of significant inflammatory change.

In the dermis, significantly increased staining with PKC- $\beta$, predominantly in dendritic cells, was observed in all of the dermatoses studied $(P<0 \cdot 05)$, except for lamellar ichthyosis and non-bullous ichthyosiform erythroderma (data not shown). Increased dermal staining with CD1a was observed in CTCL, atopic dermatitis, allergic and irritant contact dermatitis, but not psoriasis, lamellar ichthyosis, or non-bullous ichthyosiform erythroderma (data not shown).

\section{Urushiol-induced allergic contact dermatitis}

We performed a detailed time-course analysis of PKC$\beta$ and CD1a expression following the topical application of urushiol to previously sensitized subjects. PKC- $\beta^{+}$epidermal LC number was significantly reduced, compared with normal skin, at $1 \mathrm{~h}$, and this was accompanied by a reduction in $\mathrm{CD} \mathrm{a}^{+}$epidermal LCs (Fig. 4). The numbers of PKC- $\beta^{+}$and $\mathrm{CD} 1 \mathrm{a}^{+}$ epidermal LCs remained lower than in normal skin for the duration of this study (up to $48 \mathrm{~h}$ ) (Fig. 4). It is of interest that no increase in PKC- $\beta$ or CD1a dermal staining was observed until $24 \mathrm{~h}$ (data not shown), suggesting that the increase in this population of cells is not related to early migration of PKC$\beta^{+}$and $\mathrm{CD} \mathrm{a}^{+}$epidermal LCs to the dermis.

\section{Discussion}

In psoriatic lesional skin, $\mathrm{Ca}^{2+}$-dependent $\mathrm{PKC}$ activity, PKC- $\alpha$ and $-\beta$ protein levels, and epidermal LC PKC- $\beta$ immunostaining are significantly decreased, indicating previous activation of PKC- $\alpha$ and $-\beta$, with subsequent down-regulation. ${ }^{7}$ In the present study, we investigated whether these changes are specific for psoriasis, by examining PKC- $\alpha$ and PKC- $\beta$ expression in normal skin and a variety of inflammatory and hyperplastic skin diseases. We have extended our previous observations in normal $\operatorname{skin}^{7}$ to clearly demonstrate co-expression of PKC- $\beta$ and $\mathrm{CD} 1 \mathrm{a}$ by epidermal LCs. Furthermore, we have demonstrated that modulation of epidermal and dermal LC PKC- $\beta$ expression occurs in a number of inflammatory and hyperplastic skin diseases, with distinct underlying pathogenic mechanisms.

The distinct patterns of distribution of PKC isoenzymes among tissues suggests isoenzyme functional specificity. ${ }^{6,17}$ The intensity of PKC- $\beta$ immunostaining by LCs observed in the present and previous studies, ${ }^{7,11,12}$ suggests abundant LC PKC- $\beta$ expression. This is further supported by the observation that removal of $\mathrm{CD}_{1} \mathrm{a}^{+}$LCs from epidermal cell suspensions, using immunomagnetic beads, results in a significant reduction of $\mathrm{Ca}^{2+}$-dependent PKC activity and PKC- $\beta$ protein. ${ }^{7}$ Recent evidence suggests that activation of PKC induces migration of LCs from mouse epidermis, ${ }^{16}$ and that TPA treatment of murine epidermis prior to sensitization inhibits contact hypersensitivity. ${ }^{14}$ Furthermore, PKC is involved in macrophage activation required for interaction with $\mathrm{T}$ cells, ${ }^{33}$ and $\mathrm{PKC}$ may also be activated through HLA-DR class II molecules. ${ }^{34}$ Thus, it is possible that PKC may play a fundamental part in LC function and antigen presentation.

There is clearly a complex relationship between PKC- $\beta$ and CD1a expression by LCs in both the epidermis and dermis (Fig. 3 and Table 1). A reduction of PKC- $\beta^{+}$epidermal LCs without a reduction in $\mathrm{CD} \mathrm{a}^{+}$epidermal LCs in CTCL, as well as in psoriasis (Fig. 3 and Table 1), indicates that activation and 
down-regulation of LC PKC- $\beta$ is not unique to psoriasis.

One possible explanation for the reduction in PKC$\beta^{+}$epidermal LCs in urushiol-induced allergic contact dermatitis and SLS-induced irritant contact dermatitis is movement of PKC- $\beta^{+}$CD1a ${ }^{+}$LCs out of the epidermis, as $\mathrm{CD} \mathrm{a}^{+}$epidermal LCs were also decreased in number (Fig. 3 and Table 1). On the other hand, the apparent reduction in the number of $\mathrm{CDla}^{+}$epidermal LCs may reflect depletion of epidermal LC surface CD1a, with retention of normal numbers of LCs within the epidermis, as has been observed following exposure of human skin to UVB or PUVA. ${ }^{35,36}$ However, previous studies have shown reduction of ATPase $^{+}$epidermal LCs during the early afferent phase $(4-24 \mathrm{~h})$ of allergic contact dermatitis in mouse and human skin, ${ }^{37,38}$ and accumulation of epidermal LCs in draining lymph nodes has been reported after application of contact allergens. ${ }^{39}$ The role of LCs in irritant contact dermatitis is less well defined, but a reduced $\mathrm{CD} \mathrm{a}^{+}$epidermal LC number, and increased $\mathrm{CD} 1 \mathrm{a}^{+}$LCs in afferent lymph, have been reported following exposure to SLS. ${ }^{15,40,41}$ It is of interest that recent studies have indicated that movement of epidermal LCs out of the epidermis is mediated by activation of PKC. ${ }^{16}$ The reduced ratio of PKC $-\beta^{+} / \mathrm{CD} \mathrm{a}^{+}$epidermal LCs in urushiol-induced allergic contact dermatitis, and SLS-induced irritant contact dermatitis, compared with normal skin (Fig. 3 and Table 1), indicates modulation of epidermal LC PKC $-\beta^{+}$, and suggests activation and subsequent down-regulation of PKC- $\beta$. The application of urushiol to sensitized subjects resulted in a reduction in the number of PKC- $\beta^{+}$and $\mathrm{CD} 1 \mathrm{a}^{+}$epidermal LCs within $1 \mathrm{~h}$ (Fig. 4), during the pre-erythematous phase, and prior to lymphocyte entry. ${ }^{26}$ We therefore suggest that activation of PKC- $\beta$ may transduce the signal which initiates LC migration out of human epidermis. Thus, activation of epidermal LC PKC- $\beta$ may play an important part in the early phase of allergic and irritant contact dermatitis. Urushiol is a weak PKC agonist and may, therefore, directly activate LC PKC, ${ }^{42}$ although the signal resulting in activation of $\mathrm{PKC}-\beta$ may relate to antigen processing or release of keratinocyte-derived cytokines. ${ }^{43}$ SLS-induced activation and down-regulation of epidermal LC PKC- $\beta$ may account, in part, for decreased $\mathrm{Ca}^{2+}$-dependent $\mathrm{PKC}$ activity in SLS-treated epidermis. ${ }^{44}$

In atopic dermatitis, we confirmed an increase in $\mathrm{CD} \mathrm{a}^{+}$epidermal LCs compared with normal skin $^{32}$ (Fig. 3 and Table 1). Modulation of epidermal LC
PKC- $\beta$ in atopic dermatitis, indicated by a reduced ratio of $\mathrm{PKC}-\beta^{+} / \mathrm{CD} 1 \mathrm{a}^{+}$epidermal LCs, suggests that PKC- $\beta$ may be involved with other LC functions, in addition to migration.

Although hyperplasia and active inflammation were observed in the majority of disease states studied, reduced epidermal LC PKC- $\beta$ expression was observed in the absence of a significant inflammatory infiltrate in lamellar ichthyosis and non-bullous ichthyosiform erythroderma, suggesting the possibility of keratinocyte-LC interaction. Also, reduction of epidermal LC PKC- $\beta$ occurred during the very early stages of urushiol-induced allergic contact dermatitis, prior to lymphocyte entry. This suggests that direct effects of urushiol ${ }^{42}$ or, more probably, keratinocytederived cytokines, ${ }^{43}$ may account for activation and down-regulation of epidermal LC PKC- $\beta$.

In conclusion, modulation of LC PKC- $\beta$ is not unique to psoriasis, and occurs in other skin diseases. Indeed, we observed down-regulation of LC PKC- $\beta$ in all of the inflammatory and hyperplastic skin diseases which we studied. Although this may suggest that modulation of PKC $\beta$ is a non-specific event, distinct patterns of PKC- $\beta$ and $\mathrm{CD} 1 \mathrm{a}$ alterations were observed among the diseases studied. In particular, down-regulation of PKC- $\beta$ was associated with reduced $\mathrm{CD} 1 \mathrm{a}^{+}$ epidermal LCs in allergic and irritant contact dermatitis. In mice and humans, activation of PKC has been implicated in migration of LCs out of the epidermis, ${ }^{15,16}$ and our data therefore suggest that activation of epidermal LC PKC- $\beta$ may be involved in initiating outward migration of LC in allergic and irritant contact dermatitis. Whether modulation of epidermal LC PKC- $\beta$ observed in other inflammatory and hyperplastic diseases is concerned with altered migration of epidermal LCs requires further study, but PKC- $\beta$ may also be involved in other LC functions, for example LC-T-cell interactions. ${ }^{14,33}$ In the present study, we investigated skin diseases characterized by epidermal hyperplasia and inflammation, because PKC is known to regulate these processes. Whether epidermal LC PKC- $\beta$ is modulated in skin diseases with different pathogenic mechanisms requires further study.

\section{Acknowledgments}

We thank Ted Hamilton for expert statistical advice. Supported in part by the British Association of Dermatologists Dowling Travelling Fellowship and the Psoriasis Association (N.J.R.), and the Babcock Dermatologic Endowment, Ann Arbor, MI, U.S.A. 


\section{References}

1 Nishizuka Y. The molecular heterogeneity of protein kinase C and its implications for cellular regulation. Nature 1988; 334: 661-5.

2 Nishizuka Y. Intracellular signalling by hydrolysis of phospholipids and activation of protein kinase C. Science 1992; 258: 60714.

3 Reynolds NJ. Talwar HS, Baldassare JJ et al. Differential induction of phosphatidylcholine hydrolysis, diacylglycerol formation and protein kinase $\mathrm{C}$ activation by epidermal growth factor and transforming growth factor-alpha in normal human skin fibroblasts and keratinocytes. Biochem J 1993; 294: 535-44.

4 Osada S, Mizuno K, Saido TC et al. A new member of the protein kinase $\mathrm{C}$ family, nPKC theta, predominantly expressed in skeletal muscle. Mol Cell Biol 1992: 12: 3930-8.

5 Selbie LA, Schmitz-Peiffer C. Sheng Y. Biden TJ. Molecular cloning and characterization of PKC-iota, an atypical isoform of protein kinase C derived from insulin-secreting cells. J Biol Chem 1993; 32: 24296-302.

6 Wetsel WC, Khan WA, Merchenthaler I et al. Tissue and cellular distribution of the extended family of protein kinase $\mathrm{C}$ isoenzymes. J Cell Biol 1992; 117: 121-33.

7 Fisher GJ, Tavakkol A, Leach $\mathrm{K}$ et al. Differential expression of protein kinase $\mathrm{C}$ isoenzymes in normal and psoriatic skin: reduced expression of protein kinase C-betall in psoriasis. J Invest Dermatol 1993; 101: 553-9.

8 Reynolds NJ. Baldassare JJ. Henderson PA et al. Translocation and down-regulation of protein kinase $\mathrm{C}$ isoenzymes-alpha and epsilon by phorbol ester and bryostatin-1 in human keratinocytes and fibroblasts. J Invest Dermatol 1994; 103: 364-9.

9 Schaap D, Parker PJ. Expression, purification, and characterization of protein kinase C-epsilon. J Biol Chem 1990; 265: 7301-7.

10 Nakanishi H, Brewer KA. Exton JH. Activation of the zeta isozyme of protein kinase $\mathrm{C}$ by phosphatidylinositol 3,4,5-triphosphate. J Biol Chem 1993; 268: 13-16.

11 Koyama Y, Hachiya T, Hagiwara M et al. Expression of protein kinase $\mathrm{C}$ isozyme in epidermal Langerhans cells of the mouse. J Invest Dermatol 1990; 94: 677-80.

12 Koyama Y, Fukaya Y, Ueda H et al. Expression of protein kinase C isozyme in human Langerhans cells. Acta Derm Venereol (Stockh) 1991; 70: 502-5.

13 Gupta AK, Fisher GJ, Elder JT et al. Sphingosine inhibits phorbol ester-induced inflammation, ornithine decarboxylase activity, and activation of protein kinase C in mouse skin. J Invest Dermatol 1988: 91: 486-91.

14 Kodari E, Pavone A, Reiners JJ. Induction of suppressor T cells and inhibition of contact hypersensitivity in mice by $12-0$ tetradecanoylphorbol-13-acetate and its analogs. J Invest Dermatol 1991; 96: 864-70.

15 Lisby S, Baadsgaard O, Cooper KD, Vejlsgaard GL. Decreased number and function of antigen-presenting cells in the skin following application of irritant agents: relevance for skin cancer? J Invest Dermatol 1989; 92: 842-7.

16 Halliday GM, Lucas AD. Protein kinase $\mathrm{C}$ transduces the signal for Langerhans' cell migration from the epidermis. Immunology 1993; 79: 621-6.

17 Hug H. Sarre TF. Protein kinase $\mathrm{C}$ isoenzymes: divergence in signal transduction? Biochem J 1993; 291: 329-43.

18 Hawley-Nelson P. Stanley JR, Schmidt J et al. The tumor promoter, 12-O-tetradecanoylphorbol-13-acetate accelerates keratinocyte differentiation and stimulates growth of an unidentified cell type in cultured human epidermis. Exp Cell Res 1982: 137: 155-67.
19 Griffiths CEM, Esmann J, Fisher GJ et al. Differential modulation of keratinocyte intercellular adhesion molecule-I expression by gamma interferon and phorbol ester: evidence for involvement of protein kinase $\mathrm{C}$ signal transduction. Br J Dermatol 1990; 122: 333-42.

20 Barker JNWN, Mitra RS, Griffiths CEM et al. Keratinocytes as initiators of inflammation. Lancet 1991; 337: 211-14.

21 Bartel RL, Marcelo CL. Voorhees JJ. Partial characterization of phospholipase $\mathrm{C}$ activity in normal, psoriatic uninvolved, and lesional epidermis. J Invest Dermatol 1987; 88: 447-51.

22 Fisher GJ, Talwar HS, Baldassare JJ et al. Increased phospholipase C-catalyzed hydrolysis of phosphatidylinositol-4,5-bisphosphate and 1,2-sn-diacylglycerol content in psoriatic involved compared to uninvolved and normal epidermis. I Invest Dermatol 1990; 95: 428-35.

23 Bergers M, van de Kerkhof PC, Happle R, Mier PD. Membranebound phospholipase $\mathrm{C}$ activity in normal and psoriatic epidermis. Acta Derm Venereol (Stockh) 1990; 70: 57-9.

24 Horn F, Marks F, Fisher GJ et al. Decreased protein kinase C activity in psoriatic versus normal epidermis. J Invest Dermatol 1987; 88: 220-2.

25 Fisher GJ. Harris VA. Voorhees JJ. Purification and characterization of calcium/phospholipid-dependent kinase from adult human epidermis. J Invest Dermatol 1987; 89: 484-8.

26 Griffiths CEM, Barker JNWN, Kunkel S, Nickoloff BJ. Modulation of leucocyte adhesion molecules, a T-cell chemotaxin (IL-8) and a regulatory cytokine (TNF-alpha) in allergic contact dermatitis (rhus dermatitis). Br J Dermatol 1991; 124: 519-26.

27 Fisher GJ. Esmann J, Griffiths CEM et al. Cellular, immunologic and biochemical characterization of topical retinoic acid-treated human skin. J Invest Dermatol 1991; 96: 699-707.

28 Griffiths CEM, Finkel LJ, Tranfaglia MG et al. An in vivo experimental model for effects of topical retinoic acid in human skin. $\mathrm{Br} J$ Dermatol 1993; 129: 389-94.

29 Hidaka H, Tanaka T, Onoda K et al. Cell type-specific expression of protein kinase $\mathrm{C}$ isozymes in the rabbit cerebellum. J Biol Chem 1988: 263: 4523-6.

30 Baldassare JJ, Henderson PA, Burns D et al. Translocation of protein kinase $\mathrm{C}$ isozymes in thrombin-stimulated human platelets. J Biol Chem 1992; 267: 15585-90.

31 Allen MH, Markey AC, MacDonald DM. The development of a reproducible immunocytochemical technique for demonstrating colocalized cutaneous antigens. Am J Dermatopathol 1991; 13:221-7.

32 Uno H, Hanifin JM. Langerhans cells in acute and chronic epidermal lesions of atopic dermatitis, observed by L-dopa histofluorescence, glycolmethylacrylate thin sections and electron microscopy. J Invest Dermatol 1980; 75: 52-60.

33 Jayaraman S. Mensi N, Webb DR. Dorf ME. Involvement of protein kinase $\mathrm{C}$ in competence induction of macrophages to generate $\mathrm{T}$ suppressor cells. J Immunol 1991; 146: 4085-91.

34 Brick-Ghannam C, Huang FL, Temime N, Charron D. Protein kinase $\mathrm{C}$ activation via human leucocyte antigen class II molecules. J Biol Chem 1991; 266: 24169-75.

35 Aberer W, Schuler G, Stingl G et al. Ultraviolet light depletes surface markers of Langerhans cells. J Invest Dermatol 1981; 76: 202-10.

36 Friedmann PS, Ford G, Ross J, Diffey BL. Reappearance of epidermal Langerhans cells after PUVA therapy. $\mathrm{Br}$ J Dermatol 1983; 109: 301-7.

37 Bergstresser PR, Towers GB, Streinlein JW. Natural and perturbed distribution of Langerhans cells: response to ultraviolet light, heterotopic skin grafting and dinitrofluobenzene sensitization. J Invest Dermatol 1980; 75: 73-7. 
38 Rees J. Friedmann PS. Langerhans cells in squamous cell carcinoma. Arch Dermatol 1990; 126: 247-8.

39 Kripke ML, Munn CG, Jeevan A et al. Evidence that cutaneous antigen-presenting cells migrate to regional lymph nodes during contact sensitization. J Immunol 1990; 145: 2833-8.

40 Ferguson J. Gibbs JH, Beck JS. Lymphocyte subsets and Langerhans cells in allergic and irritant patch test reactions: histometric studies. Contact Dermatitis 1985; 13: 166-74.

41 Brand CU. Hunziker T, Limat A, Braathen LR. Large increase of Langerhans cells in human skin lymph derived from irritant contact dermatitis. Br J Dermatol 1993; 128: 184-8.
42 Weissmann G, Azaroff L, Davidson S, Dunham P. Synergy between phorbol esters, 1-oleyl-2-acetyl glycerol, urushiol and calcium ionophore in eliciting aggregation of murine sponge cells. Proc Natl Acad Sci USA 1986; 83: 2914-18.

43 Eng AH, Katz SI. Early molecular events in the induction phase of contact sensitivity. Proc Natl Acad Sci USA 1992; 89: 1398402.

44 Tuschil AF, Griffiths CEM, Voorhees JJ, Fisher GJ. The irritant sodium lauryl sulfate activates protein kinase $\mathrm{C}$ and induces type I transglutaminase in human epidermis in vivo. J Invest Dermatol 1994; 102: 580 (Abstr.). 
This document is a scanned copy of a printed document. No warranty is given about the accuracy of the copy. Users should refer to the original published version of the material. 